К. А. Качайло

\title{
СТРУКТУРНО-СЕМАНТИЧНІ ОСОБЛИВОСТІ ПОХІДНИХ ІМЕННИКІВ У ПОЕЗІЇ ГРИГОРІЯ ЛІЩЕНЮКА
}

Качайло К. А. Структурно-семантичні особливості похідних іменників у поезії Григорія Ліщенюка.

У статті в дериваційному аспекті розглянуто поетичні твори Григорія Ліщенюка, сучасного письменника рідного краю; визначено словотвірну структуру похідних іменників, зафіксованих у досліджуваних віршах; з'ясовано особливості семантики дериватів, утворених суфіксальним, конфіксальним, префіксальним, безафіксним способами творення, а також шляхом основоскладання та морфологосинтаксичним способом (субстантивацією).

Ключові слова: словотвірний тип, словотвірна структура, семантика, дериват.

Качайло К. А. Структурно-семантические особенности производных имен существительных в поэзии Григория Лищенюка.

(ㄷ К. А. Качайло, 2016.

-178- 
В статье в деривационном аспекте рассмотрены поэтические произведения Григория Лищенюка, современного писателя родного края; определена словообразовательная структура производных имен существительных, зафиксированных в исследуемых стихотворениях; установлены особенности семантики дериватов, образованных суффиксальным, конфиксальным, префиксальным, безаффиксным способами образования, а также путем сложения основ и морфолого-синтаксическим способом (субстантивацией).

Ключевые слова: словообразовательный тип, словообразовательная структура, семантика, дериват.

Kachaylo K. A. Structural-semantic features of derivative in Gregory Lischenyuk's poetry.

The article deals with Gregory Lischenyuk's poetry in the derivation aspect. It defines derivational structure of derivative nouns, fixed in the studied poems; establishes the peculiarities of the semantics of derivatives which have been formed with a help of suffix, confix, prefix, without affix as well as by stem composition and morphological and syntactic way (substantivation).

The Productivity of word-formation types and the potency of morphemes are displayed in the description of the eighteen suffixes, affixes, as well as lexical and wordbuilding groups of studied derivatives. Suffixes -к-, -ин(а), -ість showed high productivity, seven formants (-нн(я), -ець, -ок, -от(а), -ств(о), -иц(я), -ик) - average productivity and eight affixes (-чик, -ар, -ц-, -очк-, -ичк-, -ечк-, -ив(о), -тель) were less productive.

Comprehensive analysis of the factual material allowed to identify: derived words with the suffix -к-; derivatives with formant $-и н(а)$; word-formation type with the suffix -ість; derivatives with suffixes -нн(я) and -ець; nouns with affixes -ок and -от(а); with formants -ств(о), -иц(я), -ик; linguistic units with suffixes -чик, -ар, -ц-, -очк- in the wordformative structure; derived words with formants -ичк-, -ечк-, -ив(о), -тель.

It is defined that nouns formed by stem-composition constitute compound words, which are formed by pure composition and the one that is accompanied with suffixes on such models: «N + V»: листопад, буревій, сінокіс; «Adj. + N»: сухоцвіт, жовтоцвіт, живопліт; «V + N»: падолист, болиголов; «N + N»: небокрай, волосожар, листожар; «Pr + N»: всесвіт; «Num. + N»: сорокоуст; двобій; «Pr. + N + -н(я)»: сьогодення; «N+ V + -ець»: іконописець.

In Gregory Lischenyuk's poems derivatives with a value of the result of action formed without affix are fixed. These are verbal masculine nouns: погляд, полон, щем; as well as the verbal feminine nouns: розлука, розплата, зневіра. The presence of derivatives without affixes in the poetry of Gregory Lischenyuk accentuates their deep content; it gives a certain uniqueness of each work.

The derived words, formed with a help of confix, are functional. They have an interesting and diverse semantics and word-formation structure. Confix structures are presented by nouns which are formed with a help of confix formants.

Key words: word-formation type, word-formation structure, semantics, derivative.

\section{У сучасній лінгвістиці вивчення українського словотвору} відбувається в різних напрямках. Відомі праці П. Білоусенка, 
К. Городенської, В. Горпинича, В. Грещука, Я. Закревської, I. Іншакової, В. Німчука, О. Меркулової, С. Панцьо, Н. Клименко, О. Кубрякової, Н. Тишківської та інших.

Мовознавці приділяють увагу й вивченню в дериваційному аспекті мови прози та поезії, зокрема особливості структури й семантики оказіональних іменників із абстрактним значенням у мовотворчості Т. Мельничука та С. Сапеляка описує К. Дюкар [1], актуалізацію семантики лінгвальних засобів традиційного словника поезії П. Гірника з'ясовує Н. Ладиняк [2], словотвірну структуру і функції абстрактних іменників в оповіданнях Оксани Забужко розглядає Л. Приблуда [3].

3 огляду на те, що українська література на початку XXI століття збагатилася новими творами, та все більш актуальним стає вивчення творчості письменників рідного краю, доречним i своєчасним, на нашу думку, є дослідження в дериваційному аспекті поетичних творів митця з Кіровоградщини Григорія Ліщенюка.

Мета статті - 3'ясувати структурно-семантичні особливості похідних іменників, використаних у поезії Григорія Ліщенюка.

Григорій Васильович Ліщенюк (1956 року народження) нині працює єгерем у Петрівському УТМР, має кілька збірок поезій, які вийшли друком протягом останніх років. Як показує фактологічний матеріал, мова творчого доробку Григорія Ліщенюка (збірки «Жовтоцвіти», «Сорокоуст. Сонети», «Тридцять три осінні сонети») насичена великою кількістю похідних іменників, утворених різними способами словотворення. Серед ста шістдесяти дібраних дериватів сто чотири мовних одиниці утворені за допомогою суфіксації, дев’ятнадцять іменників - шляхом основоскладання, п'ятнадцять - безафіксним способом, одинадцять - способом конфіксації, по шість похідних слів утворено префіксальним та морфолого-синтаксичним способом.

За даними фактологічного матеріалу, найбільша кількість похідних іменників утворена за допомогою суфіксального способу творення (64\% від загальної кількості проаналізованих дериватів), тому важливо простежити продуктивність словотвірних типів та активність морфем. Зважаючи на те, що у словотвірній структурі досліджуваних слів виокремлено вісімнадцять суфіксальних формантів, подальший виклад матеріалу здійснено 3 урахуванням зменшення рівня активності афіксів. На першому місці за кількістю ( К. А. Качайло, 2016. 
стоять похідні слова з суфіксом -к-. Такі деривати можна представити лексико-словотвірними групами:

- назви рослин та їх частин: гілка - В саду моєму сумно зараз досить, Гілки над головою заплелись (Тт 6); По стінах від гілок безлистих тіні (СС 8); квітка - Квітками і травою заросли Могили вамі (Тт 13); пелюстка - Вітри з дощами, ніби для забави, В далекім лузі витоптавши трави, На хризантемах пелюстки зірвуть (СС 8); травинка - Запам'ятай, щуо тут усе твоє, мала комаха і травинка кожна (Ж 18);

- найменування місцевості: стежка - Ночами часто бродить коло хати, Шука давно загублені стежки (Тт 15); верхівка - Спішать кудись отави сірі хмар, Торкаючись тополі до верхівки (Тт 25); бруківка - Дощ цзяхами свинцевими прибив Дукати листя просто до бруківки (Тт 25);

- назви одягу: сорочка - Ти ж істину єдину пам'ятай - Своя сорочка ближче в них до тіла (CC 17); хустка - I бродить попід вікнами журба, Закутавшись у чорну хустку ночі (Ж 17);

- найменування результату виконаної дії: думка - Мій давній друже нині я хворію, Роями надокучливих думок (Тт 5); звичка - Все поміняєш - погляди і звички (Тт 7);

- найменування приміщень та їх частин: домівка - У дядька Лева затишно в домівці (Тт 26); иибка - В розбиту шибку ріжусь нанівець (Тт 5); Ще пахне димом крізь розбиту шибку (Тт 25); Закашляє, неначе дід недужий, Забивиись в иибку хворими грудьми (СС 14);

- назви предметів: фіранка - Гойдає вітер на вікні фіранку (Тт 25); нитка - Немов нитки, сотаю їх в клубок I на долонях, як дитя лелію (Тт 5); сторінка - Невпинно пам'ять сторінки гортає (Тт 13);

- найменування частин тіла та результату психічної діяльності: кістка - Вологий холод до кісток пройма (Тт 14); сльозинка - За ним він ллє на землю почорнілу Сльозинки рос, ще важчі, аніж град (СС 11);

- назва птаха: пташка - Покинула гніздо остання пташка (Тт 33); Рвуть крилами на клапті хмари сині Пташки, які не вернуться назад (СС 11);

- найменування музичного інструмента: сопілка - Там Лукаш Мавиі грає на сопілці (Тт 26);

- назва явища природи: іскорка - Вогонь, щзо в кузні батьковій горів, Тепер в мені лиш іскоркою тліє (Тт 24). 
Далі за кількістю йдуть деривати $з$ формантом -ин(a), їх можна класифікувати за такими лексико-словотвірними групами:

- назви місцевості: долина - Блукає сірий ранок у долині (Тт 14); глибина - Яка блакитна неба глибина, Я б в ній розтанув, якби були крила (Тт 4); мілина - Мій човен весь дрижить на мілині, Бортами об гранітні скелі б'ється (СС 28); бистрина - Спішіть у сни по синій бистрині (СС 35); чужина - Чужина довкола, чужсина, Дні короткі тонуть у журбі (Ж 4);

- найменування одиничних предметів 3 ряду однорідних: краплина - Роса стіка на землю по краплині (Тт 14); Збираю смуток по малій краплині (СС 38); Збираю літо в жменю по краплині (Тт 30); Над літом, щзо згоріло по краплині, Вони «Сорокоуст» читають нині, Мені до ранку спати не дають (СС 8); комишина - Всю душу розтривоживши до сліз, На комишині вітер грає соло (Ж 22); стеблина - В знедоленій краӥні, там де ти Існуєш, мов стеблина при дорозі (СС 17); свитина - Під вікнами сумує листопад У мокрій $з$ листя жовтого свитині (СС 11);

- назви певних проміжків часу: хвилина - Хапаюся безсило за життя, А жити залишаються хвилини (Тт 12); давнина - I ніби диво сталося зі мною, В мені озвався голос давнини (СС 19);

- найменування приміщення: хатина - Стара хатина, дах сніпками вкритий, Ніколи час ї̈ не шкодував (Тт 15); В покинутій хатині зі стіни Я зняв стару, занедбану ікону (СС 19);

- назви явищ природи: хуртовина - Як холодно в цій жовтій хуртовині (Тт 17); павутина - Думки снуються ніби павутина, Обволікають мозок мій повільно (Тт 12);

- найменування стану людини та опредмеченої ознаки: самотина - Як холодно в оцій самотині (Тт 9); сивина - Гірчить квітучих вишень білий дим I падає на скроні сивиною (Ж 17).

Наступним за продуктивністю є словотвірний тип із суфіксом -icmb. Дібрані іменники - абстрактні назви, що представлені такими лексико-словотвірними групами:

- найменування певних психічних якостей, що стосуються осіб: совість - А совість інше, щуо там говорити (Тт 16); вірність - I щуоб тирану вірність доказати, Ще гризлись між собою, як вовки (СС 26); свідомість - Моє життя свідомість, як в кіно, Назад перемотати не забуде (CC 15);

() К. А. Качайло, 2016. 
- назви певних фізичних якостей, що стосуються осіб: cmарість - I буде тобі старість за сестричку (Тт 7); Від старості ніде не заховатись (СС 43); кульгавість - Кульгавість - то була лише дрібниия (СС 20); бідність - Їй долею судилось горювати I в бідності свої дожити дні (СС 20);

- найменування певних ознак предметів: вартість - Багато в цімм житті було турбот, Які сьогодні вартості не мають (Тт 32); буйність - Поселитись в лісах чи в степу серед буйності трав (Ж 26);

- назва просторово-часового періоду або проміжку: вічність Стискаю вічність у єдину мить (Тт 5); безкінечність - Летять у безкінечність день за днем (Ж 17).

Однакову кількість складають деривати 3 суфіксами -нн(я) та -ець і представляють такі лексико-словотвірні групи:

- назви опредмеченої дії: кохання - Лягають на папір сумні рядки Обманутого долею кохання (Тт 24); бідування - Я пережив митарства й бідування (СС 23); віршування - А ввечері сідав за віршування (СС 23); страждання - Забувши про хворобу і стражждання (СС 23);

- найменування результату дії: прощання - Я нині сам на острові прощання (Тт 4); Пора прощань пропахла полинами (Тт 34); прозріння - світлий час прозріння, Все має свій початок $і$ кінець (Тт 7); нагадування - Волога твоя тягнеться до рук, Нагадуванням спаленого літа (Тт 17); визнання - Що при жстті визнання не знайшов (СС 23); рубецьь - Сотні Небесної Шлях - Вічний на сериі рубець (Ж 5); терпець - Але колись увірветься терпець (СС 36);

- назви осіб за характерними ознаками: сліпець - Збираючи метафори ночами, Навпомачки блукаю, мов сліпець (Тт 5); мудрець «Всьому свій час, - повів колись мудрець. - Час розкидати $і$ збирать каміння» (Тт 7); мрець - Короткий день, блідий неначе мрець, Лежить на білім савані зі снігу (Тт 12); ловецьь - Компрачікоси - доль чужих ловці (Тт 21);

- найменування меблів: стілець - О, як вам дуже хочеться корони, Щоб троном став звичайний ваш стілець (СС 36);

- назви грошових одиниць: червінець - Сиплють клени червінці кругом, Обдаровують золотом осінь (Ж 16).

Іменники 3 афіксами -ок та -оm(a) класифікуємо за такими лексико-словотвірними групами:

- назви періодів доби: ранок - Прокинеться росою ранок 
вмитий (Тт 15); Вони «Сорокоуст» читають нині, Мені до ранку спати не дають (СС 8); темнота - Час темноти $i$ світлий час прозріння, Все має свій початок і кінецьь (Тт 7);

- найменування місця: куток - Лежить у кутку кімнати, Не хочеться йти нікуди (Ж 13); висота - Вони себе понад усе любили, Завжди хотіли тільки висоти (СС 41);

- назви частин рослин, виробів 3 них: листок - Я зірваним листком здаюся нині (Тт 22); вінок - Неначе у вінок дрібні квітки, Вплітаю в храм поезї рядки (Тт 3); сніпок - Стара хатина, дах сніпками вкритий (Тт 15);

- найменування станів людини: самота - Гойдає вітер гнізд порожніх тишу, Минає час в холодній самоті (Тт 23); гіркота Далекий спогад гіркоту приносить (Тт 6); турбота - Сьогодні в неї лиш одна мурбота - Рахує дні до осені вона (Тт 30).

Поодинокими прикладами представлені назви осіб: свідок - $A$ свідками моӥми були грати, Перо, папір та щее журливі дні (СС 27); найменування хвороби: сухоти - Сухоти роздирають мої груди, Я знаю, скоро вже мене не буде, Та буде слово - вічне і святе (Тт 28); абстрактна назва: марнота - Все, врешті-решт, марнота із марнот (Тт 32).

Невелику кількість похідних слів складають деривати із суфіксами -ств(о), -иц(я) та -ик. Означені іменники можна поділити на такі лексико-словотвірні групи:

- назви людських якостей та вмінь: лукавство - Отак в лукавстві згинете усі (Тт 19); акторство - Та вам изого здається недоволі, Ще хочете акторства, далебі (Тт 19); нахабство - Та їм, бувало, вистачало сили Своїм нахабством, щзо не мало меж (СС 41);

- найменування споруд та їх частин: в'язниця - Набудували стільки вже в'язниць, Що ними край увесь заполонили (СС 39); віконниця - Віконницями вітер сонно грима (Тт 5); криниця - У вибалках криниця ледь жива (Тт 17);

- назви водного транспорту: вітрильник - Гойда вітрильник сивий океан (Тт 21); кораблик - Кораблики із мрій моӥх далеких, Спішіть у сни по синій бистрині (СС 35).

Одним прикладом представлені групи: назви місця: ияарство Неквапно час у изьому царстві лине (Тт 12); найменування періоду життя людини: дитинство - I лиш пам'яті сивої схрон Зберігає дитинство далеке (Ж 23); найменування предмета: дрібниця ( ) К. А. Качайло, 2016. $-184-$ 
Кульгавість - то була лише дрібниця (СС 20); назва комахи: метелик - Метеликом барвистим уночі, Розгойдується полум'я свічі (Тт 8).

Частина суфіксальних дериватів налічує по кілька мовних одиниць (з формантами -цик, -ap, -ц-, -очк- у словотвірній структурі), а інша частина - по одному прикладу (з суфіксами -ичк-, -ечк-, -ив(о), -тель). Доречно їх об’єднати в такі лексико-словотвірні групи:

- назви певних спеціальних предметів: тягар - I станеш тягарем ти сам собі (Тт 7); хабар - За хабарі усякому годив (СС 40); сильце - Життя летить так швидко, наче птах, Але в сильце його ти не спіймаєш (СС 43); ниточка - Старезний клен до ниточки промок (Тт 25); І сонний ранок бродить по долині В промоклому до ниточки плащчі (CС 18);

- найменування місцин: кінчик - Збираю смуток по малій краплині На кінчику тоненького пера (СС 38); окрайчик - I правдами, i кривдами, та все ж Окрайчик щзастя часом ще ловили (СС 41); плетиво - I безкінечне плетиво доріг, Мені покірно стелиться до ніг (Тт 11); В мені живуть лісів зелені крони, Високі скелі, плетиво ожин (Тт 27); джерельие - Тепер усе віддав би залюбки, Аби устами до ї̈ руки Припасти, наче спраглий до джерельця (СС 9);

- назви осіб за сімейними стосунками та видом діяльності: сестричка - I буде тобі старість за сестричку (Тт 7); служитель Хто і коли вас научив так жити, Служителі безпринщипних ідей? (Тт 19); Смішні людйі, служителі мамони (СС 36);

- найменування пори року: літечко - Збираються з негодами вітри, По літечку відправить панахиду (Тт 22);

- назва частини тіла тварини: мордочка - Всю мордочку струпи вкрили Котові, щуо зветься Васька (Ж 13).

Іменників, що утворилися шляхом основоскладання зафіксовано дванадцять відсотків від усієї кількості досліджуваних дериватів. Дібрані 3 поетичних творів Григорія Ліщенюка складні слова, утворені способом чистого основоскладання, i такого, що супроводжується суфіксацією. Усі проаналізовані похідні іменники можна представити такими моделями:

- «іменник + дієслово»: листопад - Тепер шукати марно поміж трав, Те щзо давно вже листопад забрав (Тт 5); Під вікнами сумує листопад У мокрій з листя жовтого свитині (СС 11); буревій - Солому тут і там повиривав, зі стріхи буревій несамовитий (Тт 15); Тривога все 
єство моє проймає, I на душі - неначе буревій (СС 21); сновида - Вона ночами схожа на сновиду (Тт 22); сінокіс - Вже косами не дзвонить сінокіс, Стернею поколовши вітру ноги (СС 10); казнокради - Лакеї, казнокради й бюрократи Месіями сьогодні хочуть стати (СС 29);

- «прикметник + іменник»: сухоцвіт - Як холодно в оцій самотині, Стаю поволі жовтим сухоцвітом (Тт 9); жовтоцвіти Жовтоцвіти мої, жовтоцвіти ... Сірий день на морозі зачах (Ж 3); живопліт - Кує літа зозуля у саду Та й кидає усі за жнвопліт (Ж 26);

- «дієслово + іменник»: падолист - Фарбує жовтень сонну далечінь Та падолисту поки що немає (Ж 17); болиголов - Бо кругом поріс болиголов, Густо так, щуо й стежки не знайти (Ж 23);

- «іменник + іменник»: небокрай - Пливуть мої літа до небокраю, Як те вербове листя восени (Тт 32); волосожар - Спиваю сірий сум посеред ночі, Волосожар виблискує в імлі (Тт 10); листожар - В саду господарює листожсар (Тт 25);

- «займенник + іменник»: Всесвіт - Навколо сіра каламуть чатує, Та иілий Всесвіт з болю і тривог (Тт 14);

- «числівник + іменник»: Сорокоуст - Вони «Сорокоуст» читають нині, Мені до ранку спати не дають (СС 8); двобій - Я знаю, щзо не вернуся з двобою, Але моя душа завжди з тобою (Тт 26);

- «займенник + іменник +- -н(я)»: сьогодення - Із сьогодення $y$ минуле рвуся, Шукаю там змарнованих років (Тт 20);

- «іменник + дієслово + -ець»: іконописець - Здалося, я іконописця знав, Не раз вели ми дружню з ним розмову (СС 19).

За семантикою складні слова виявилися назвами осіб (іконописець, казнокради, сновида), найменуваннями природних явищ (буревій, листопад, падолист), назвами часово-просторового характеру (Всесвіт, сьогодення, небокрай), найменуваннями рослин і предметів, зроблених з них (сухоцвіт, жовтоцвіти, живопліт, болиголов), назвами діяльності людей (двобій, сінокіс), найменуванням результату мовленнєвої діяльності (Сорокоуст).

Безафіксним способом, за нашими даними, утворено деривати зі значенням опредмеченої дії або результату дії, яку називає твірна основа (9 \%), їх можна поділити на такі групи:

- віддієслівні іменники чоловічого роду: погляд - Bce поміняєш - погляди $і$ звички (Тт 7); полон - Я хочу спати, тільки де той сон, Коли зима взяла все у полон (Тт 12); політ - Летять як $i$ ( К. А. Качайло, 2016. $-186-$ 
колись невпинно дні, Лише в політ усіх не запросили (Тт 13); поклонПоклони відбиваєте доземно, Вже й бачите себе на небесі (Тт 19); щем - Неначе б то у вирій відлітаю, До відчаю стискає груди щем (Тт 31); причал - Хай до причалу так $і$ не приб'юся, Як добре, щзо глибин я не боюся (СС 28);

- віддієслівні іменники жіночого роду: розлука - Оця розлука, Боже, як гірчить (Тт 9); завія - Коли зима потоне у завіях, Мене це не злякає ні на мить (Тт 11); оселя - Блукає ніч по закутках осель (Тт 13); зажура - Взяв листопад усе в полон зажур (Тт 33); розплата - Історія не вміє пробачати, I час розплати завжди настає (Тт 35); розмова - Не раз вели ми дружню з ним розмову (СС 19); зневіра Лише не хочу вмерти у зневірі (СС 21); забава - То це душі схотілося забави (СС 30); втома - Та раптом ненароком помічаєм безмежну втому у своїх очах (СC 43).

Далі за кількістю йдуть похідні слова, утворені конфіксальним способом творення (7 \%). Дібрані з поезій деривати характеризуються цікавою семантикою та словотвірною структурою. Так, наприклад, 3 постпозитивним компонентом -/й/(a) у структурі словотвірної морфеми наявні іменники зі значенням:

- те, що не містить чогось, названого твірною основою: без-... -/й/(a) - безгоміння - Поринути колись у безгоміння тут кожному судилося із нас (Ж 27); не-...-/й/(a) - небуття - Його забрала вічність в небуття (СС 32); Міст в небуття невидимий, хисткий, Але усі перейдемо по ньому (Ж 18);

- те, що називає сукупність чого-небудь, названого твірною основою: $\boldsymbol{c y - . . . - / и ̆ / ( а ) ~ - ~ с у ц в і т т я ~ - ~ К а н у т ь ~ в ~ Л е т у ~} i$ болі, $і$ втрати, I суцвіття зів'яне за мить (Ж 3);

- те, що називає результат після чогось, названого твірною основою: по-...-/й/(а) - похмілля - Болить твоя з похмілля голова (CC 33);

- те, що обрамляє щось, назване твірною основою: об-...-/ü/(a) - обличчя - Спотворених облич весела маска, Скаліченого тіла не шкода (Тт 21); Знайомі риси час з обличчя стер, Лиш згадую, щуо брови мав кошлаті (СС 32).

За даними фактологічного матеріалу, деякі деривати утворені шляхом приєднання конфіксів 3 другими компонентами -ок, -иц(я) та матеріально не вираженою другою частиною, наприклад: за-...-ок: 
закуток - Блукає ніч по закутках осель (Тт 13); про-...-ок: просвіток - Навколо ніч, ні просвітку нема (СС 27); ви-...-ок: вибалок - У вибалках криниця ледь жива (Тт 17); по-...-иц(я): потилиця - O, як ви вміли вправно, залюбки Безвинним у потилиці стріляти! (СС 26); по-...ө: повітря - Лелечий сум повітря напоїв (Тт 17); Достиглим плодом пахне у повітрі (СС 24); Повітря перегіркло полинами (Ж 19); позолота - Що позолота з кленів обліта (СС 10).

Незважаючи на невелику кількість похідних, семантика проаналізованих конфіксальних іменників $\epsilon$ цікавою та різноманітною, тому що вони $є$ назвами: частини тіла людини: обличчя, потилиця; певного місця: закуток, просвіток, вибалок; абстрактного поняття: небуття; частини рослини: суцьвіття; явищ природи: повітря, позолота.

Іменників, утворених шляхом префіксального способу творення, виявилось небагато - $4 \%$ від усієї кількості проаналізованих дериватів. Найбільш активним є префікс не-, який надає похідним словам значення заперечення, через що вони виступають антонімами до мотивуючих слів і належать до таких лексико-словотвірних груп:

- назви характерних якостей особи: нещирість - Нещцрості до себе не дозволю Й себе їй на поталу не віддам (Тт 29);

- найменування певних станів: неспокій - Холодної зими важка хода Відлунює тривогу і неспокій (Ж 13); невдача - Суцільна смуга із одних невдач (Тт 8); неволя - Моє життя - неволя, біль і втрати, Свої роки найкращі їм віддав (СС 27);

- назва особи: недруг - Hi друга, а ні недруга немає (Тт 14).

Префікс без- у досліджуваних мовних одиницях виступає зі значенням відсутності чогось, названого твірною основою. За нашими даними, це лише один дериват - абстрактна назва, вжита у невластивій для неї формі множини: безнадія - Вони, здається, згодом всі розбились Об гострі скелі сірих безнадій (СС 47).

Зібраний фактологічний матеріал засвідчує дію морфологосинтаксичного способу при творенні деяких похідних іменників (4 \%). Так, наприклад, субстантивовані прикметники використовуються на позначення назв осіб: перехожий - На себе з боку глянеш крадькома, Як перехожий дивиться на дурня (СС 33); прохожий - Тепер прохожий навіть не помітить Отого, щзо забулося давно (СС 42); лукавий - Аби ї̈ не спокушав лукавий, Ховалася аж на самомудні (СС 30); безвинні - O, ( К. А. Качайло, 2016. $-188-$ 
як ви вміли вправно, залюбки Безвинним у потилиці стріляти! (СС 26). Субстантивовані дієприкметники є назвами, які означають щось, що в часовому вираженні було колись: забуте - I сум липкий та чорний наче сель, В забуте хвору душу повертає (Тт 13); минуле - Ви ж як посли, 3 минулого приходите неждано (Тт 13).

Отже, словотвірний аналіз похідних іменників, утворених суфіксальним способом, показав, що 3 вісімнадцяти суфіксів, які

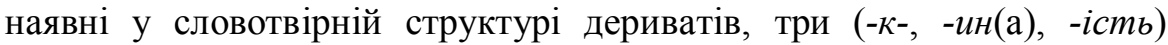
виявили високу активність, сім (-нн(я), -ець, -ок, -от(а), -ств(о), -иц(я), $-и \kappa)$ - середню, а вісім формантів (-чик, -ар, -и-, -очк-, -ичк-, -ечк-, -ив(о), -тель) були малоактивними. Складні іменники, які використані у поетичних творах письменника, хоча й представлені невеликою кількістю похідних, мають цікаву семантику й різноманітну словотвірну структуру. Наявність безафіксних іменників у поезії Григорія Ліщенюка увиразнює іï зміст, надає певної образності та неповторності кожному віршу. Конфіксальні структури, віднайдені у трьох збірках письменника, представлені іменниками, що утворені за допомогою десяти конфіксальних формантів. Щодо префіксальних дериватів, то невелика їх кількість обумовлюється й тим, що цей спосіб творення $є$ малопродуктивним у словотвірній системі іменника. Прикметною рисою ідіостилю Григорія Ліщенюка є використання похідних слів, які утворені морфолого-синтаксичним способом (субстантивацією). Описані похідні іменники свідчать про оригінальну авторську позицію у відтворенні художньої дійсності засобом реалізації стилетвірного потенціалу дериватів.

\section{Література}

1. Дюкар К. В. Особливості структури й семантики оказіональних іменників із абстрактним значенням у мовотворчості Т. Мельничука та С. Сапеляка [Електронний pecypc] / К. В. Дюкар. - Режим доступу : http://movoznavstvo.com.ua/download/ pdf/2013_1/18.pdf

2. Ладиняк Н. Б. Актуалізація семантики лінгвальних засобів традиційного словника поезії П. Гірника [Електронний ресурс] / Н. Б. Ладиняк. - Режим доступу : http://science.kpnu.edu.ua/wp-content/uploads/sites/7/2014/pdf/ohie/9/1_10.pdf

3. Приблуда Л. М. Словотвірна структура і функції абстрактних іменників в оповіданнях Оксани Забужко [Електронний ресурс] / Л.М.Приблуда. - Режим доступу : http://dspace.nuft.edu.ua/jspui/handle/123456789/476

\section{Список умовних скорочень джерел}

Ж - Ліщенюк Г. Жовтоцвіти / Григорій Ліщенюк. - Кіровоград: ЦентральноУкраїнське видавництво, 2014. - 70 с. 
СС - Ліщенюк Г. Сорокоуст. Сонети / Григорій Ліщенюк. - Кіровоград: Центрально-Українське вид-во, 2013. - 48 с.

Тт - Ліщенюк Г. Тридцять три осінні сонети / Григорій Ліщенюк. - Кіровоград, 2011. $-35 \mathrm{c}$.

Стаття надійшла до редакиії 20.10.2015 p. 